DOI: https://doi.org/10.29038/2227-1376-2021-38-124-137

\title{
DISTRUST AS A PSYCHOLOGICAL PHENOMENON
}

\author{
Kravchenko Viktoriia
}

Ivano-Frankivsk National University of Oil and Gas

Ivano-Frankivsk city, Ukraine

vikakravchenko@ukr.net

ORCID: http://orcid.org/0000-0002-7615-946x

\section{Shastko Iryna}

Ivano-Frankivsk National University of Oil and Gas

Ivano-Frankivsk city, Ukraine

2992@ukr.net

ORCID: http://orcid.org/0000-0001-6963-2899

Purpose. The article provides a theoretical analysis of the problem of mistrust as a psychological phenomenon that is closely related to trust.

Methods. To achieve the purpose of the study, methods of psychosocial approach are used (because mistrust is manifested both internally and externally); subjective approach (because mistrust is an independent psychological phenomenon); system approach (allows to take into account all connections, types, forms, criteria of trust-distrust, as well as determinants, consequences, functions). With the help of these methods the essence of distrust is revealed, which has its own criteria and features.

Results. Analysis of domestic and foreign works on the psychological phenomenon of mistrust allows us to consider it as a means of ensuring human existence in the global world. Along with other sciences (philosophy, sociology, culturology, economics), which study trust - distrust, psychology has a number of methodological and technological problems. The connection between self-confidence and trust in the world is investigated. The task of the study is to determine the essence of distrust; to trace the connection between trust in oneself and trust in the world; to expand the notion of distrust as a means of personal security; to study distrust as a personality trait. An important point in the existence of a balance of self-confidence and trust in others is the level of self-reflection (awareness, spirituality), which will provide a person with peace and acceptance in an unknown difficult situation or fear and rejection, which often drives a person to act non-stereotypically or stereotypically.

Conclusions. In general, it can be concluded that mistrust can manifest itself in

ISSN 2308-3743 (Online), ISSN 2227-1376 (Print)

(C) Кравченко B., Шастко I., 2021. Ця стаття відкритого доступу на умовах CC BY-NC 4.0 
suspicion, jealousy, inner tension, "protection", naivety, conformity, dogmatism, negativism, skepticism, intimophobia, unwillingness to make long-term plans, fear of change, excessive propensity to engage. The existence of a balance of self-confidence and trust in others is the level of self-reflection (awareness, spirituality), which will provide a person with balance and self-efficacy in solving life's problems.

Keywords. Trust, distrust, credulity, safety, danger.

\section{Кравченко Вікторія, Шастко Ірина. Недовіра як психологічний феномен.}

Мета статті - здійснити теоретичний аналіз проблеми недовіри як психологічного феномену, що тісно пов'язаний з довірою.

Методи. Для реалізації мети дослідження використано методи психосоціального підходу (оскільки недовіра проявляється як на внутрішньому, так і на зовнішньому рівнях); суб'єктного підходу (оскільки недовіра самостійний психологічний феномен); системного підходу (дає змогу врахувати всі зв'язки, види, форми, критерії довіри-недовіри, а також детермінанти, наслідки, функціï). За допомогою цих методів розкрито сутність недовіри, що має свої критерії та особливості.

Результати. Аналіз вітчизняних i зарубіжних студій дав підстави розглядати психологічний феномен недовіри як засіб безпечності існування людини в глобальному світі. Як і інші науки, що досліджують довіру - недовіру (філософія, соціологія, культурологія, економіка), психологія містить низку нерозв'язаних методичних і технологічних проблем. Актуальним вбачається дослідження зв'язку довіри до себе та довіри до світу. Саме тому в цьому дослідженні визначено сутність недовіри; простежено зв'язок довіри до себе й довіри до світу; розширено уявлення про недовіру як засіб безпечності особистості; вивчено недовірливість як особистісну рису. Визначено, що запорукою рівноваги довіри до себе і довіри до інших є наявність певного рівня саморефлексії (усвідомленості, духовності), що забезпечує людині спокій i прийняття в невідомій складній ситуації або ж страх і неприйняття, що часто спонукає людину діяти нестереотипно чи навпаки - шаблонно.

Висновки. Отже, недовіра може проявлятися в підозрілості, ревнивості, внутрішній напрузі, «захисті», наївності, конформності, догматизмі, негативізмі, скептицизмі, інтимофобії, небажанні будувати довгострокові плани, страхові змін, надмірній схильності до узагальнень тощо. Важливим моментом в існуванні рівноваги довіри до себе і довіри до інших $є$ рівень саморефлексії, що і забезпечить людині баланс та самоефективність у вирішенні життєвих проблем.

Ключові слова. Довіра, недовіра, довірливість, безпека, небезпека.

\section{Кравченко Виктория, Шастко Ирина. Недоверие как психологический феномен.}

Цель. В статье осуществлен теоретический анализ проблемы недоверия как психологического феномена, что тесно связан с доверием. 
Методы. Для реализации цели исследования используются методы психосоциального подхода (поскольку недоверие проявляется как на внутреннем, так и на внешнем уровнях); субъектного подхода (поскольку недоверие является самостоятельным психологический феномен) системного подхода (позволяет учесть все связи, виды, формы, критерии довериянедоверия, а также детерминанты, последствия, функции). С помощью данных методов раскрывается сущность недоверия, его критериев и особенностей.

Результаты. Анализ отечественных и зарубежных работ к психологическому феномену недоверия позволяет рассматривать его как средство безопасности существования человека в глобальном мире. Наряду с другими науками (философией, социологией, культурологией, экономикой), которые исследуют доверие - недоверие, психология имеет ряд методических и технологических проблем. Исследуется связь доверия к себе и доверия к миру. Задачей исследования является определить сущность недоверия; проследить связь доверия к себе и доверия к миру; расширить представление о недоверии как средства безопасности личности; изучить недоверчивость как личностную черту. Важным моментом в существовании равновесия доверия к себе и доверия к другим является уровень саморефлексии (осознанности, духовности), что и обеспечит человеку покой и принятие в неизвестной сложной ситуации или страх и неприятие, часто движет человека действовать нестереотипно или, наоборот, шаблонно.

Выводы. Таким образом, недоверие может проявляться в подозрительности, ревности, внутреннем напряжении, «защите», наивности, конформности, догматике, негативизме, скептицизме, интимофобии, нежелании строить долгосрочные планы, страха перемен, чрезмерной склонности к обобщениям и тому подобное. Важным моментом в существовании равновесия доверия к себе и доверия к другим является уровень саморефлексии (осознанности, духовности), что и обеспечит человеку баланс и самоэффективность в решении жизненных проблем.

Ключевые слова. Доверие, недоверие, доверительность, безопасность, опасность.

Introduction. Academic interest to the study of trust - distrust has appeared recently, in the middle of 90 -s of the XX century. Notably, social request for its study has originated from practical needs of contemporary information society. Along with other sciences (philosophy, sociology, culture studies and economics) that study trust - distrust, psychology has a number of methodologic and technologic problems. The article aims at theoretical analysis of distrust as a psychological phenomenon. The task of the study is to disclose essence of distrust; trace connection between selftrust and trust in the world; expand the concept of distrust as a method to protect individual; study incredulity as a personality trait. 
Methods. Theoretical and methodological bases of the study of distrust are: psychosocial approach (since distrust is shown both at inner and outer levels); subjective approach (as distrust is a separate psychological phenomenon); fundamentals of spiritual-moral psychology (because trust-distrust is involved in individual's self-control and value spheres); systematic approach (allows to consider all connections, types, forms, criteria of trust-distrust as well as determinants, consequences and functions).

Results and discussion. Trust - is an ability of a person a priori indue phenomena and objects of surrounding world and other people, their future actions and own actions with characteristics of safety (reliability) and usefulness (significance) (Skripkina, 2000: 85). Trust as a psychological attitude includes interest and respect towards an object or a partner; idea of needs that may be satisfied as a result of interaction between them; emotions from the expectation of their satisfaction and positive appraisal of the partner; relaxation and unconditional readiness to show good attitude and do certain actions that facilitate successful interaction (Kupreichenko, 2008: 59). Distrust, in its turn, includes the following elements: perception of risks; sense of danger, fear impaired with negative emotional appraisals of the partner and possible results of cooperation; vigilance and tension and, also, readiness to end contact, respond to aggression or show cautionary hostility (Kupreichenko, 2008: 60).

According to the degree of expression of psychological attitude of trust "genuine" and "false" trust/distrust are distinguished, and, respectively, include: expectation of rewards, positive emotional appraisals and readiness of the subject to moral behavior and fear of evil, negative appraisals and readiness to end contact or hostility. False trust may be the result of extrajection and a kind of false, deceivable relations or their imitation ("pseudo-trust", "pseudo-distrust") that are used to manipulate partner (Kupreichenko, 2008: 69).

Species of "genuine" trust/distrust are "trust proper" and "distrust proper". By "trust proper" we mean attitude built as a result of verified data of objective appraisement of people and objects of surrounding world as trustworthy. "Distrust proper" is a checked, reasoned appraisement of people and objects of surrounding world as untrustworthy. Certain criteria and functions are developed to distinguish between these species of trust/distrust, however, the main content (expectations, concept and emotional appraisal) may remain the same (Kupreichenko, 2008: 70). 
Distrust is often regarded as a method to protect individual. It is related to contemporary living conditions of people in the global world which requires increase of intensity of people's interaction with different social institutions, internet and human isolation. Ye. Ilin (2013) defines the most vulnerable categories of credulous people, who get into troubles, who actually lack distrust. Among these are: women, pensioners, children, vulnerable population. (Ilin, 2013: 57). He also adds here lie (deceit), classified as manipulation of people's consciousness. There are different kinds of lies, but its genuineness centers around recognition and availability of meaningful purpose (Ilin , 2013: 60). Lying is evident mostly due to nonverbal signs Ekman P. (2009). Respectively, these signs help to reveal lies and manipulation. Sheremeta V.Yu. (2007) studies problem trust-distrust in the context of nonverbal human behavior. Complex approach is needed to interpret nonverbal signs that partners in conversation use during communicative process, it helps to understand each other better. There are signals in the system of nonverbal signs that immediately impel human to trust in this situation (open postures, sincere smile, intimate communication zone, common territory, etc.) or, vise a versa, not to trust (closed posture, insincere smile, closed space, etc.). People are actually socialized through harmonious trust-based communication positively enhanced by nonverbal signals (Sheremeta, 2007).

Structure of psychology of safety is considered in two aspects: psychological safety of the environment and psychological safety of an individual. Psychological safety is an integrated category, as it is studied from few perspectives: as a process, as a quality of the state and as a personal trait; and what is more - at several levels: at the level of society, at the level of individual's local environment and at the level of personality. Criteria of psychological safety are: referential significance of the environment (reflected in the positive attitude to it); contentment by interpersonal communication; protection from psychological violence (Baraniuk, 2019: 14). In our opinion, distrust may only be safety means at an external level and by no means can be safety bases at a level of personality. (Kravchenko, 2019: 246).

It supports the idea, that imbalance of the self-trust and trust in the world leads to unreasonable credulity and categorization of the trust in the world (Kravchenko, 2019: 246). Consequently, self-distrust appears, that can be investigated as a separate psychological phenomenon. Even under 
the condition of long lasting and close relations between people, still it's not possible to exactly predict future actions of a person, whom an individual trusts. Thus, trust is always a risk (absence of safety). The only guarantee of trusting relationships is to treat others as oneself. It is exactly where connection between self-trust and trust in others appears and is realized in affiliation. When a person is not afraid to trust oneself as an independent, harmonious person, then he/she is able to trust others and, thus, treats them same way. Furthermore, truly harmonious person is always moderate: at the same time open to the world and to oneself (Kravchenko, 2019: 247). Accordingly, in this context distrust can be regarded as a separate psychological phenomenon, related to trust. In support of this thought, some authors (Skripkina, 2000; Antonenko, 2004) consider trust and distrust phenomena, opposing one another, and not related. Others prove, that trust and distrust do not depend on each other (Lewicki, McAllister, Bies, 1998) seeing that consequences in relations between people are not predictable and definitive.

Hjelle L., Ziegler D. (2003) investigate distrust from the perspective of the feeling of fear, suspicion and dark presentiments. Reasons might be: belief that others are only intended to use people, that trust is not built at once, it takes a lot of time, trust is a delicate subjective phenomenon, built hard and slowly, but easily and quickly lost (Ilin, 2013: 65).

A. Kupreichenko, S. Tabkharova (2007) define symmetric (for example, morality - amorality, reliability - unreliability, openness secrecy, independence - dependence, not prone to conflicts - proneness to conflicts, etc.) and asymmetric criteria of trust and distrust (for example, highly appreciated force, activity, optimism of the partner appear as peculiarly relevant criteria of trust to others, nevertheless, weakness, passiveness, pessimism for the majority of respondents are not distrust criteria). Thus, trust and distrust can be considered as a relatively independent (separate) psychological phenomena which have similar and different characteristics.

Scientists also examine distrust from the perspective of a personality trait - incredulity (protension) (Raigorodskii, 2000: 235). Credulity - is a reception of the partner as a person, who will not use obtained information against partner due to his/her moral qualities (Ilin, 2013: 67). Correspondingly, credulity is a worldview of the person, including faith in people. Incredulity as a personality trait expresses suspicion, jealousy, inner tension, "defense" (Raigorodskii, 2000: 235). According to the 
degree of credulity - incredulity were distinguished naivety, conformity, dogmatism, negativism, skepticism (Ilin, 2013).

Naivety is a personality trait that reflects high level of credulity (simplicity) (Ilin, 2013: 68). Often it is absence of life experience; expression of an unconscientious wish to escape reality, stop conceiving reality as it is; unwillingness or inability to predict (Ilin , 2013). Infantilism is close to naivety, it is a retention of qualities characteristic of the infant age in human psyche (Stepanov, 2006: 161). It is clear, that in order to raise level of trust to oneself (stop being naive and infantile) it is necessary to undertake responsibility for everything that happens in person's life. Conformity is a propensity of the individual to change behavior, convictions and attitude under the pressure of the group. Level of conformity depends on characteristics of the individual who yields to the group pressure, his/her relations with a group and content of a task performed (Stepanov, 2006: 177). There is a great number of reasons and explanations of conforming behavior in psychology based on self-distrust. Dogmatism is an inert, one-way schematic thinking characterized by the use of dogmas, in other words, fixed beliefs, accepted as an indisputable truth that does not require any proof, disregarding particular circumstances, place and time based on blind subordination to the authority (Stepanov, 2006: 110). Negativism is an unmotivated opposition of the subject depending on his actions; negative pattern, attitude to people with negative prejudice (Ilin, 2013: 84). Selective negativism may be displayed at a communicative, behavior and deep level. Actually, here complete distrust in others and at the same time in oneself is expressed. Skepticism is a critical distrustful attitude to something, doubts about genuineness and rectitude of something. Symptoms: distrust, incredulity, lack of faith, nihilism, suspicion (Ilin, 2013: 85). It often emerges in difficult life situations when self-trust and trust in the world is totally lost.

Ye. Ilin relates to incredulity as a personality trait fear of intimacy, unwillingness to build long-term plans, fear of changes and propensity to generalization, and gives general recommendations how to gradually eliminate distrust: realize negative experience of distrust, generalize list of stereotypes-distrust and dispel it with real examples from other people's lives and make a list of positive examples of trust-based relations (Ilin, 2013: 90).

Criteria of distrust as a display of attitude to other people is investigated in science in the context of three main processes: formation, 
justification and overcoming distrust (Kupreichenko, 2008: 147). According to A. Kupreichenko's model we distinguish criteria of distrust of an individual in others that are considered through subject of appraisal and main processes of distrust. Respectively, we will examine selfappraisal, appraisal of conditions and appraisal of other people. Selfappraisal at the stage of formation of distrust includes appraisal of the personal vulnerability and competence in recognition of danger. The most significant personal determinants are: common self-distrust, distrust in others and the world mindset (suspicion and hostility, general or opportunistic); conception of own social incompetency, vulnerability. Appraisal of conditions includes environment factors and psychological situation, influence of social group, finding living environment where trust in person is acceptable and trust limits are set in the present circumstances, at the stage of distrust formation includes appraisal of how great uncertainty and risks are. The most significant personal determinants are: idea of absence of circumstance under which one can "open" to the other person and existence of conflict of interests. Appraisal of the other person that includes his/her significance, capability to change conditions of the environment, own characteristics and characteristics of others, at the stage of distrust formation includes appraisal of personal qualities that incur distrust. The most significant personal determinants are: notion of secrecy of the partner in conversation and existence of negative characteristics (propensity to conflicts, unsuccessfulness, dependency, etc.). Or characteristics of the "stranger"; significance of these characteristics; idea of the role and place of this person in socio-psychological space (Kupreichenko, 2008: 148).

Self-appraisal at the stage of justification of distrust presupposes appraisal of possible losses and personal ability to decrease losses; appraisal of danger justification. The most significant personal determinants are: subjective significance of possible losses; self-appraisal of qualities that can minimize losses (internal locus of control, cautiousness, self-command, optimism) or increase them (credulity, pessimism, aggressiveness). Appraisal of conditions at the stage of justification of distrust includes estimation to what extent the existing circumstances can be harmful and how to protect oneself. The most significant personal determinants are: idea of the possibility to neutralize danger, in particular, institutional norms (institutional distrust). Appraisal of the other person at the stage of justification of distrust includes 
appraisal of the wish and ability of the other to cause harm and appraisal of weaknesses of the partner in conversation. The most significant personal determinants are: idea of availability of qualities, which may cause the greatest harm, or, vice versa, stop partner in conversation and, also, the idea of his/her weaknesses, role and place in socio-psychological space of the person (Kupreichenko, 2008: 149).

At the stage of coping with distrust self-appraisal presupposes appraisal of the personal wish and competency in existing situation. The most significant personal determinants are: responsibility, self-confidence; idea of personal morality, good intentions and interest in long-term relationships. Appraisal of conditions at the stage of overcoming distrust presupposes appraisal of the possibility to shorten psychological distance in given conditions. The most significant personal determinants are: idea of safety assurance or conditions that allow improvement of relationships (for example, by changing sphere or nature of interaction, assistance in critical situation, etc.). Appraisal of the other person at the stage of overcoming distrust presupposes determination of qualities that allow to count on cooperation. The most significant personal determinants are: idea of moral qualities of the partner, his/her predictability and interest in relationships; idea of his weaknesses, his/her role and place in sociopsychological space of the person (Kupreichenko, 2008: 149).

Such outlining of the structure of criteria of person's distrust in others, evidences, that trust and distrust appear as relatively independent phenomena, that may exist simultaneously in relation to one and the same object (or subject) and be evident in ambivalent appraisals. Ambivalence as a stable quality (property) displayed in co-existence of almost equal in strength, mutually acceptable, opposite feelings, thoughts and acts in relation to or (and) personal, inner world is a dynamic characteristic of the personality. It acts as a variable behavior regulator in all spheres of human life, psychological features of which are determined by the particularity of personality development responding inconsistency of the contemporary life. High tension of ambivalence is a part of motivational struggle, which acquires constructive and destructive forms. If highly ambivalent situation remains unsettled for a long period of time, tension, and in reality these are human sufferings, finds its expression in individual and group aggressive acts. At the same time, moderate ambivalent tension facilitates balance, integration of inconsistencies and acceptance of negative and positive aspects of own personality and forwards personal advancement (Shastko, 
2011). Herewith, trust and distrust criteria are influenced most of all by person's attitude to him/herself, his/her identity which determines selfdetermination, level of self-consciousness of the personality (integration of ambivalence) and value-orientation sphere, integrating all personality orientation constellations, therefore, its self-concept, having its conative expression in dominated influence of this sphere on person's behavior and activities (Karpiuk, 2012).

According to the structural model of self-trust V. Kravchenko (2019) distinguishes self-trust and self-distrust. Self-distrust includes such intrapersonal construct as: self-favorableness, inner strife, self-blaming and self-destruction that sets in motion incentive variable ("I-want") and leads to incomprehension of oneself. Excessive trust in the world and at the same time self-distrust are determined by the low self-esteem. Excessive self-trust and at the same time distrust in the world depends on the inflated self-esteem. Self-distrust exists on the operational level and self-trust at reflexive (Kravchenko, 2019: 250). Dynamic balance of selftrust and trust in the world is aimed at assuring personality's integrity and authenticity. And, vice versa, absolute priority given to self-trust and trust in the world leads to destructive tendencies in formation of intrapersonal relations and development of self-concept and disturbance of harmony in relationships (Kravchenko, 2019: 251).

Deformation of trust-based relations may become evident in three ways: excessive expression of self-trust, that in the end leads to problems in relations with other people and narrowing of the circle of trust-based relations; heightened level of trust in others results in lowered self-esteem of the individual, level of strivings, high anxiety and frustration; level of self-trust and trust in the world may at the same time decrease and is called trust crisis (Skripkina, 2006). Moreover, there exists a trust deprivation concept, which means absence of the need to enter into close trust-based relations with people around against lowered level of self-trust and attitude to others as to things. Insufficient trust to people around with adequate or inflated level of self-trust and unsatisfied need to trust (Skripkina, 2006: 560). These lead to maladjustment of the person. It is clear, that selfdistrust is studied as a separate psychological phenomenon related to certain level of self-trust.

Any object of the surrounding world and the world on the whole inspires with trust only when they are characterized by the safety (reliability) and significance (value) (Skripkina, 2000). When a person 
assigns these qualities to the object he/she may ambivalently and contradictory treat them. If significance (value) of the object for the individual is greater that his/her safety, interaction becomes risky. It is explained by the fact that person, trusting in oneself, may not only interact with the world, but change, re-built it. Ability to trust oneself allows an individual to leave limits of the situation and create a new one, by breaking the postulate of expediency, adaptiveness. Thus, risky behavior and nonadaptive activities may be considered as a manifestation of trust in oneself, related to the trust in the world (Kravchenko, 2019: 245). When an individual acquires an experience of interaction with certain objects, he/she builds connection with them, because, he/she already knows to what extent they may be trusted. Level of trust in the world corresponds to the usual level of self-trust. Consequently, we can speak of the activity related to reproductive kinds of activity, relative integrity of the personality. It is often when such needs and situations (problem situations) arise and a person has no ready forms of behavior and usual means of interaction. As an individual is always trying to be consistent with the world and oneself, there are two ways to remove inconsistencies in problem situation: raise level of self-trust and trust in the world. In the first case (when significance, value of the own subjectivity is increased) appear non-adaptive forms of activity, related to risk, creative initiative. If one shall achieve positive result (the need shall be satisfied by means of creative self-realization) level of self-trust and trust in the world is automatically increased. In the second case, a person is trying to enhance trust in the world (raise significance and value of conditions, suggested by the world), then he/she decreases level of self-trust, and, therefore, trust in the world (Skripkina, 2000: 88). Kupreichenko A.B. (2008) has different opinion and thinks that a person does not need to leave homeostasis (balance of self-trust and trust in the world), because, he/she already has formed level of self-trust, that helps to calmly settle his/her problems, and not to risk. We think, that an important moment in existence of balance of self-trust and trust in others there is a level of self-reflection (awareness, spirituality) that assures person's peace and acceptance in unknown difficult situation or fear and rejection that often pushes person to nonstereotype or, the opposite, conventional acts.

Conclusions. In contemporary society problem of trust-distrust is most pressing. Content of the modern information environment gives rise to such psychological phenomenon as distrust. In the context of 
interpersonal relations and social interactions, distrust reflects attitude to oneself and others, accompanied by tension, suspicion, uncertainty, etc.

In order to define distrust were created certain criteria and functions, however, the main content (expectations, concept and emotional appraisal) may remain the same. There are symmetrical and asymmetrical criteria of distrust which allow to consider it an individual psychological phenomenon, related to trust. In present living conditions and global world distrust is considered as a method to protect human existence. Nevertheless, according to our research, distrust may act as an external means of safety only, but not the one, that determines human behavior at an inner (personality) level, because it forms shallow relation to others (insignificant, having no value).

Formation of personality's distrust depends on the level of self-trust and trust in the world leading to excessive credulity and categorization of the trust in the world. Self-distrust (according to Kravchenko V.Yu.) as an intrapersonal construct includes: self-favorableness, inner strife, selfblaming and self-destruction that leads to incomprehension of oneself. Excessive trust in the world and at the same time self-distrust are determined by the low self-esteem. Excessive self-trust and at the same time distrust in the world depends on the inflated self-esteem. Absolute priority given to the self-trust and trust in the world leads to destructive tendencies in formation of intrapersonal relations and development of selfconcept and disturbance of harmony in relationships. Here various deformations of trust-based relations are distinguished.

Determination of the structure of criteria of person's distrust in others (investigated in science within the framework of three main processes: formation, justification and overcoming distrust) shows that trust and distrust act as relatively independent phenomena, that can simultaneously exist in relation to one and the same object (or subject) and become evident by ambivalent appraisals.

Distrust is investigated from the perspective of personal trait incredulity (protension). It can be evidenced by suspicion, jealousy, inner tension, "defense", naivety, dogmatism, negativism, skepticism, fear of intimacy, unwillingness to build long-term plans, fear of changes, excessive propensity to generalization, etc.

An important element of existence of self-trust and trust in others is a level of self-reflection (awareness, spirituality) that assures person's balance and self-efficiency in settlement of life issues. 


\section{References}

1. Antonenko, I.V. (2004). Doverie: sotsialno-psihologicheskiy fenomen [Trust: a socially psychological phenomenon]. M. [in Russian].

2. Baraniuk, N. I. (2019). Teoretychni aspekty rozuminnia psykholohii bezpeky [Theoretical aspects of understanding psychological safety]. Psykholohiia natsionalnoi bezpeky i blahopoluchchia osobystosti : tezy I Mizhnarodnoi naukovopraktychnoi konferentsii - Proceedings of the $I^{\text {st }}$ International Research-to-Practice Conference, Psykhologiia natsionalnoi bezpeky i blagopoluchchia osobystosti, 14-15 March 2019. Lviv: Lviv Politeknika [in Ukrainian].

3. Blatt, S. (1982). Dependency and self-criticism: psychological dimensions of depression. Journal of Consulting and Clinical Psychology,50, 113-124.

4. Ekman, P. (2009). Psihologiya lzhi [Psychology of lies]. SPb.: Piter [in Russian].

5. Ilin, Ye.P. (2013). Psihologiya doveriya [Psychology of trust]. SPb.: Piter [in Russian].

6. Giddens, A. (1991). Modernity and Self-Identity. Self and Society in the Late Modern Age. Cambridge: Polity Press.

7. Jaromowic, M., Szuster, A. (2016). Self-We-Others Schemata Differentiation as a Base for Personal Agency and Social Attitudes. Frontiers in psychology, 7. DOI: https://doi.org/10.3389/fpsyg.2016.01227

8. Karpiuk Yu. Ya. (2012). Vplyv khrystyianskoi morali na tsinnisnooriientatsiinu sferu molodshykh shkoliariv [Influence of Christian ethics on valueoriented sphere of younger school children]. Extended abstract of candidate's thesis. Ivano-Frankivsk: State Higher Educational Establishment "Vasyl Stefanyk Precarpathian National University" [in Ukrainian].

9. Kravchenko V.Yu. (2019). Dovira yak chastyna struktury stiikosti osobystosti [Trust as part of the structure of personality's resilience]. Development of modern science: the Experience of European Countries and Prospects for Ukraine (P. 240 - 273). Riga: Publishing House "Baltija Publishing" [in Ukrainian].

10. Kupreichenko A.B. (2008). Psihologiya doveriya i nedoveriya [Psychology of trust and distrust]. M.: «Institute of Psychology of RAS» [in Russian].

11. Kupreichenko A.B., Tabkharova S.P. (2007). Kriterii doveriya i nedoveriya lichnosti drugim lyudyam [Criteria of trust and distrust of other people]. Psihologicheskiy zhurnal - Psychological Journal, 2, 55-67 [in Russian].

12. Keyes, C. L. M., Shmotkin, D., Ryff, C. D. (2002). Optimizing well-being: The empirical encounter of two traditions. Journal of Personality and Social Psychology, 82, 1007-1022.

13. Oldhem,J.M., Morris,L.B. (1990). The personality self-portret. New York. Toronto. London. Sydney. Auckland.

14. Beautrais,A. (2000).Risk factors for suicide and attempted suicide among young people. Australian and New Zealand Journal of Psychiatry, 34(3),420-436. DOI: https://doi.org/10.1080/j.1440-1614.2000.00691.x

15. Nolen,H. S.(2013). Abnormal Psychology. 6th ed. Boston, USA: McGrawHill. 
16. Podolskij,A. (2012). Development and Learning. In: Encyclopedia of the sciences of learning, 944-950. New-York;Heidelberg: Springer

17. Ryff, C. D. (1995). The structure of psychological well-being revisited. Journal of Personality and Social Psychology, 69, 719-727.

18. Lewicki R.J., McAllister D.J., Bies R.J. (1998). Trust and distrust: New relationships and realities. Academy of Management Review, 23 (3), 438-459.

19. Mutz,D.C. (2001). Tolerance. International encyclopedia of social and behavioral sciences, 23, 15766-15771.

20. Vaillant,G. (2000).Adaptive mental mechanisms: Their role in a positive psychology. American Psychologist, 55(1),89-98.

21. Virna, Zh. (2015). Professional Deformations: Tendencies, Dynamics and Risks of Manifestation. Annales Universitatis Mariae Curie-Skłodowska, 2(28), 123 136.

22. Skripkina, T.P. (2000). Psihologiya doveriya [Psychology of trust]. M.: «Akademija» [in Russian].

23. Skripkina, T.P. (2006). Deformatsiya doveritelnyih otnosheniy kak faktor dezadaptatsii lichnosti [Deformation of trust-based relations as factor of misadaptation of the individual]. Obschenie - 2006: na puti $k$ Entsiklopedicheskomu znaniyu: Materialyi konferentsii - Communication - 2006: Towards Encyclopedic Knowledge: Conference Proceedings. (pp. 555-561). M. [in Russian].

24. Stepanov, O.M. (ed.). (2006). Psykholohichna entsyklopediia [Psychological encyclopedia]. K.: «Akademvydav» [in Ukrainian].

25. Hjelle L., Ziegler D. (2003). Teorii lichnosti [Personality theories]. SPb.: Piter [in Russian].

26. Sheremeta V.Yu. (2007). Neverbalna komunikatsiia yak chynnyk interpretatsii doviry-nedoviry u strukturi mizhosobystisnykh vidnosyn [Nonverbal communication as a factor of interpretation of trust-distrust in the structure of interpersonal relations]. Zbirnyk naukovykh prats: filosofiia, sotsiolohiia, psykholohiia - Collection of scholarly papers: philosophy, sociology, psychology, 12, 180-185 [in Ukrainian].

27. Shastko I.M. (2011). Psykholohichni osoblyvosti perezhyvannia. ambivalentnosti latentnoho materynstva $\mathrm{u}$ divchat yunatskoho viku [Psychological specifics of experiencing ambivalency of latent maternity in juvenile girls]. Extended abstract of candidate's thesis. Kyiv: National Pedagogical Dragomanov University [in Ukrainian].

Received: 15.09 .2021

Accepted: 04.10.2021 